\title{
Ikhin Tone and Nasality: Autosegmental Effects
}

\author{
Oladimeji Olaide A. \\ Department of Linguistics and Languages, Federal University, Oye-Ekiti, Ekiti State, Nigeria \\ Opoola Bolanle T. \\ Department of Linguistics and Languages, Federal University, Oye-Ekiti, Ekiti State, Nigeria
}

\begin{abstract}
In generative phonology, tone and nasality are described as suprasegmental phonological units. This implies that their survival depends on the segments on which they are grounded. Thus, when a tone bearing unit or nasality bearing unit disappears, any of these segments also disappears. In autosegmental theory, however, tone or nasality survives after the deletion of segment to which it is attached. This phenomenon is termed 'stability' which is the foundation for autosegmental phonological theory. Stability is the survival of tone and nasality after the deletion of segments on which they are grounded. Tone and nasality exhibit stability in Ikhin, a North-Central Edoid language spoken in Edo State, South-South, Nigeria. Previous study on Ikhin dwells mainly on the phonetics of the language. This study, therefore, investigates phonological processes such as vowel elision, glide formation and nasalization with a view to determining the stability or otherwise of tone and nasality. This paper confirms that in Ikhin, any process that involves the removal of a tone bearing unit must relate to stability and relate to the creation of contour tones. The study further confirms that nasality remains stable even in the absence of segment to which it is linked. Based on available data, it is argued that the deletion of a Tone Bearing Unit (TBU) or a Nasality Bearing Unit (NBU) does not necessarily involve the deletion of tone or nasality. Infact, it usual does not. The study concludes that tone and nasality are independent segments. They are as independent as consonant and vowel.
\end{abstract}

Index Terms - Ikhin, Tone and Nasality, Autosegmental Effects, Generative Phonology, Stability

\section{INTRODUCTION}

Ikhin is a member of the Edoid family's North Central branch (Oladimeji 2013). Eastern Kwa was the name given to a group of languages that included Edoid. They are now known as Benue-Congo (BC), along with the rest of Eastern Kwa, and are recognized as forming a putative West Benue-Congo (WBC) federation (Blench1989). Delta Edoid (DE), Southwestern Edoid (SWE), North Central Edoid (NCE), and Northwestern Edoid are the four co-ordinate branches of the Edoid community (NEW). Geographically, the Edoid languages spread from the Rivers and Bayelsa States in the eastern Niger Delta, across Delta and Edo States, to parts of Ondo and Kogi States (Elugbe 1989). Ikhin is spoken in the Owan East Local Government Area (Oladimeji 2010). The speakers, who number in the thousands, live in Edo State's Owan East Local Government area, in the Northwestern part of the state (Oladimeji 2013). People give the tribal group and language the name "Ikhin" (Oladimeji 2010).

\section{Methodology}

This paper's approach is both descriptive and empirical. The data were collected from seven purposely chosen native speakers in Ikhin town and one from Ibadan, using the Summer Institute of Linguistics' 1000 wordlist and the University of Ibadan's 400 basic item wordlist as it can be seen in www.open-science-repository.com . Traditional stories, interactions, descriptive remarks and isolated unelicited utterances all provided additional data. The data were analyzed using the computerised speech laboratory's speech filing system (Oladimeji, 2010).

\section{EMPIRICAL WORKS}

Ikhin literature is uncommon. Folarin (1982) is the only existing linguistic research on this language. A Comparative Edoid Phonology (Elugbe, 1973), "A Phonology of Edo (Bini)" (Amayo, 1976), and "A Phonology of Emai" (Egbokhare, 1990) are only a few examples of studies on Edoid languages. There is no mention of Ikhin in any of the preceding.

\section{THEORETICAL FRAMEWORK}

Goldsmith's Autosegmental Theory is the theoretical framework. When analysing and presenting the data, this principle is applied. Sound Pattern of English (1968), a study by Chomsky and Halle, is widely regarded as the first systematic treatment of generative phonology. For Kenstowicz (2006), taking the notation in terms of which sounds were represented as bundles of feature was a key feature. A comprehensive collection of features as well as concepts for 
writing phonological representation was suggested. However, in the sense that it was a single line of representation, phonological representation was still linear (Opoola and Olaide, 2021).

Chomsky and Halle's first generation of graduate students successfully applied the generative phonological theory, in which systematic alternations are derived from a common underlying type by an ordered set of principles as it can be seen in www.web.mit.edu, to well known languages like Russian, Japanese, French and Spanish. A critical mass of comprehensive analyses from a generative viewpoint accrued, revealing a slew of issues and research questions - some of which remain unanswered. According to Paul Kiparsky (1968), abstract representations are motivated by alternations and grammars evolve to a state where the underlying representations can be caused by rules that state generalisation over surface phonetic representation.

Tone, nasality, stress and length phonology are not well-suited to rules that modify the structure of features in a local context. These suprasegmentals were subjected to intense examination, which had a significant impact on how sounds are interpreted and manipulated by laws of grammar (www.web.mit.edu). Though tone and nasal features are phonetically expressed as vocalic features, their phonological behavior is largely independent of segmental string. Thus, building on Wil Leben William's work, John Goldsmith (1990) proposed that tonal and nasal features be represented on a different level (tier) from the segmental tier. As a result, if tone and nasality are independent, vowels may be deleted while tone and nasality remain on their own tiers and map to an adjacent syllable for maximum association. In Ikhin, nasality relinks to the adjacent vowel across the morpheme boundary when a nasal vowel of a monosyllabic verb elides. Without mentioning the concepts of autosegmental theory, no discussion of stability will be complete. It's a non-linear approach that enables phonological processes like pitch, nasality, and vowel harmony to be independent of individual vowels and consonants and to reach beyond them. As a consequence, phonological processes can affect several vowels or consonants at once as it can be seen in www.studylove.org

This considers phonological representation, according to www.web.mit.edu, to be multi-dimensional and multi-tiered. Each tier is made up of series of segments arranged in a linear pattern. Association lines connect the tiers, indicating how the segments on each tier should be pronounced at the same time.

Autosegmental phonology, on the other hand, is an offshoot and alteration of generative phonology, which Goldsmith introduced in his $\mathrm{PhD}$ thesis. It is, he says, an effort to provide a better understanding of the phonetic side of linguistic representation. He disagrees with traditional generative phonology because it is characterised by an absolute "slicing theory", according to which a phonological representation is split into tidy "slices" or segments, each nearly organised and constructed as having no ordered subparts. Autosegmental phonology, according to Goldsmith (1976), is a proposal at the same logical level as SPE's concept that a phonological representation consists of several parallel levels of phonological segments, each of which is represented on its own tier or level and that tiers are connected. Autosegments are elements on each tier that are ordered sequentially. Association convention is the central concept of this theory.

\section{AsSOCIATION CONVENTION}

In Ikhin, each morpheme has two parts: On the one side, there is segmental material, and on the other, there is a tone. As an example, consider the following representation according to www.vanoostendorp.nl :

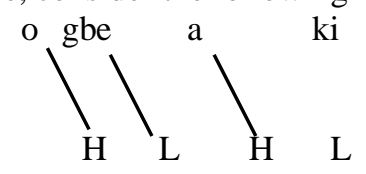

According to Association Convention in www.vanoostendorp.nl, every tone must be connected to a vowel.

a. On the surface, there are no "floating" tones; for www.vanoostendorp.nl, each tone must be associated with a vowel. The tonal association convention is part of a broader collection of phonological structure criteria that enable each element in a phonological representation to be related to the rest of the structure.

b. Align-tone: Considering other constraints of the language, according to www.vanoostendorp.nl, all tones ought to be as close to the right edge of the word as possible. Tone shifts to the right ('spread') in several tone languages around the world.

c. The Well-Formedness Condition (WFC): Each tone in the output representation should correspond to exactly one vowel, and vice versa. WFC is not absolute in all languages, as we can see later, because of its absolute existence in Ikhin. The best we can do to satisfy tone alignment to the greatest extent possible is shown below according to www.vanoostendorp.nl;

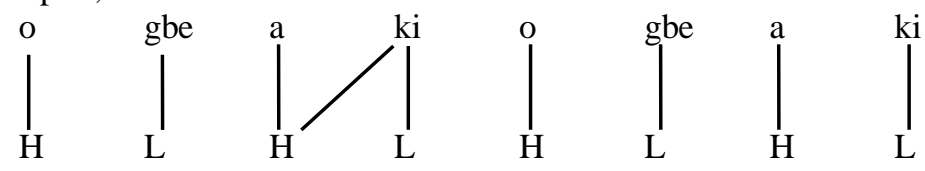

Every tone is now as closely as possible connected to the right (www.vanoostendorp.nl). It is also worth noting that the well-formedness condition encompasses a number of conditions, such as "no tone should be related to more than 
one vowel" and "no vowel should be toneless." Autosegmental theory has also proven useful in the study of contour tones. Ikhin has low, high, and contour tones, for example (The language also has downdrift, downstep and downglide).

In the theory according to www.vanoostendorp.nl, there are two approaches to coping with a case like this. We can classify the rising and falling tones as a combination of a low tone followed by a high tone, and a combination of a high tone followed by a low tone, respectively, or we can describe them as a combination of a low tone followed by a high tone. Autosegmental analysis advises us to take the latter route

\section{Stability In Autosegmental TheORY}

Autosegmental theory describes stability as a phenomenon. It refers to the persistence of tone, nasality, vowel harmony, and other features after segments on which they are based are removed. Since the syllable structure of Ikhin forbids clusters of vowels within or across word boundaries, vowel elision and glide formation are two techniques for discouraging vowel cluster in Ikhin. The two main syllable structure processes in Ikhin are vowel elision and glide formation, with vowel insertion as the third. As a result, when a vowel elides or glides, its tone is preserved, and the same is true of nasality. When a nasality-bearing unit is removed, the nasality is retained. This is stability.

\section{A. Vowel Elision and Tone Stability}

According to Opoola and Olaide (2021), in African languages in general, and in Edoid languages in particular, vowel elision is a common phonological process. Vowel elision is very common in kwa languages, where the syllable structure of verbs and nouns allows vowel sequences to occur across morpheme boundaries (Welmers, 1973). Any of the vowels (V1 and V2) will elide at the boundary in Ikhin and other Edoid languages like Urhobo, Emai, and so on, depending on the construction type. The impact of this phase on tone is a source of concern for us. Ikhin is a tone language. Pike was one of the first to provide a comprehensive description of tone language. A tone language, according to journal.ikipsiliwangi.ac.id, is one in which each syllable has lexically important, contrastive, yet relative pitch. Tone is important because it distinguishes utterances, and it is also lexical because it distinguishes the meanings of words. Pike (1948) added that tone must be constrastive in order to be lexically relevant. This means the pitches would be tonemes that contrast with each other. Since no syllable in a tone language can be pronounced without a tone, Pike's concept of tone on any syllable is a reference to a surface phenomenon.

Tone is a suprasegmental phonological unit, according to generative theory. It suggests that it is vowel-dependent. It also means that when a vowel is deleted in generative theory, the tone is also deleted. A tone, on the other hand, survives after the deletion of the vowel to which it is attached in autosegmental theory. This, according to Opoola and Olaide (2021), leads to the phenomenon of stability, which is the persistence of tone after the deletion of the section that it is based on. The tone survives the deletion of a tone-bearing unit (vowel). When two morphemes or words, one of which ends with a vowel and the other which begins with a vowel, are combined, potential vowel clusters in Ikhin can be avoided by dropping one of the vowels. Boundary deletion is the other name for this. We will see how the elision of vowels affects the status of other segments including tone and nasality in the following presentation, which uses data from Ikhin. This is because all of the affected vowels are tone-bearing units, although only a handful of them have nasality. The segments' (vowels and consonants) and tones' (tones) characteristics according to Opoola and Olaide (2021) are separated in autosegmental theory. Tones have a parallel relationship with the vowels with which they are aligned. The effects of vowel elision processes on tones will be seen in our sample derivations below for autosegmental representation of vowel elision processes. When vowels are removed, their tones are immediately set afloat and then relinked using a tonal association convention, which is a set of conditions for phonological representation to be related to other parts of the phonological structure (Opoola and Olaide, 2021).

Goldsmith's (1976) study of tone in African languages demonstrated the importance of autosegmental analysis. He argued for an autosegmental representation since phonological rules that apply separately at the tonal and segmental levels will remove a vowel while leaving the tone associated with it unchanged. Ikhin's examples are as follows:

$$
\begin{aligned}
& \text { òkò + } \text { ćdà }^{\mathrm{V}_{1} \mathrm{~V}_{2}} \\
& \mathrm{~L} \mathrm{~L} \text { òkědà } \\
& \text { 'motor' } \mathrm{H}
\end{aligned}
$$

Rule 1: $\quad$ Delete $\mathrm{V}_{1}$, but do not delete its low tone

(ii) òk' $+\quad$ ćda

After the vowel [o] is deleted, one is left with an unattached low tone. Another rule is needed:

Rule 2: The unattached (floating) low tone reconnects with the next vowel (www.ling.mq.edu.au ).

(iii) òk' + édà $\rightarrow$ òk ̌̀dà 'boat'

In the light of the above, notice that the tone on the second noun's prefix vowel [ $\varepsilon$ dà] is high [H], while the unattached (floating) tone is low [L]. The two together produce a low [L] tone followed by a [H] tone, which is the same as a rising (contour) tone. Phonologists would handle these changes using an autosegmental representation, in which tones and segments are represented separately. For instance, according to www.ling.mq.edu.au, the underlying representation for òkò + ćdà would be: 
(iv)

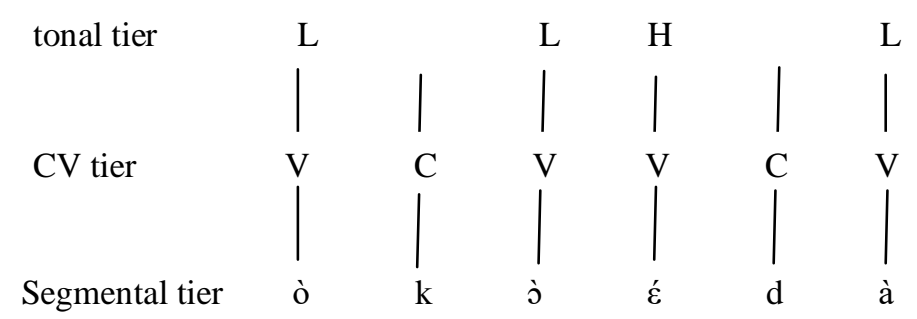

When the final vowel of the first word is followed by another vowel at a word boundary, a rule applies at the segmental level to remove it (www.ling.mq.edu.au ).

(v)

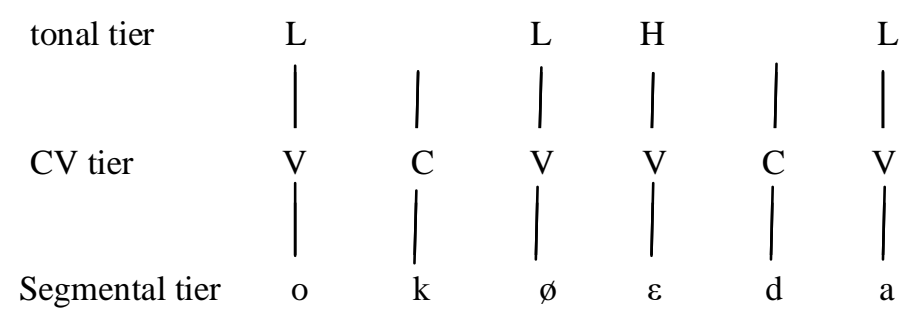

A floating low tone has now been added to the closest high tone which is attached to the nearest vowel.

(vi)

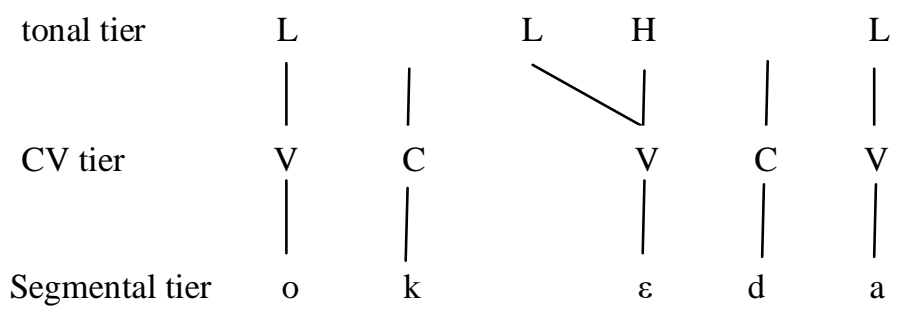

In other words, we have a LH (rising) tone attached to vowel $[\varepsilon]$, that is, the vowel $[\varepsilon]$, which is $\mathrm{V}_{2}$ at the word boundary, has an LH (rising) tone attached to it.

\section{B. Glide Formation and Tone Stability}

Glide formation is a phonological process that allows a segment to undergo a major class change by changing its major class features. It can occur within as well as across morpheme boundaries e.g.

Examples:

$$
\begin{array}{lll}
\text { (i) joíà } \rightarrow & \text { òpjà } & \text { 'matchet' } \\
\text { (ii) áxí }+ \text { àmè } & \rightarrow & \text { áxjâmè } \\
& \text { 'pot' 'water' } &
\end{array}
$$

Glide formation and vowel elision complement each other. Glide formation in Ikhin applies within or across morpheme boundaries provided the following conditions are met.

(a) $\mathrm{V}_{1}$ must be preceded by a consonant. That is, the close vowel (front and back) occurs between a consonant and a non-identical vowel, as in the frame $\mathrm{C}-\mathrm{V}, \mathrm{CV}$ -

(b) In the vowel sequence, $\mathrm{V}_{1}$ must be a close vowel (/i/ or / $\left.\mathrm{u} /\right)$ and $\mathrm{V}_{2}$ must be a non-identical vowel, provided the word that bears the $\mathrm{V}_{1}$ has the minimal structure of its lexical category.

Examples:

$$
\begin{array}{cccl}
\text { (iii) } \begin{array}{c}
\text { fi } \\
\text { 'throw' }
\end{array} & \begin{array}{c}
\text { èró } \\
\text { 'money' }
\end{array} & \rightarrow & \begin{array}{l}
\text { fjêrò } \\
\text { 'throw money' }
\end{array} \\
\text { (iv) } \begin{array}{ccc}
\text { xí } \\
\text { 'make' }
\end{array} & \begin{array}{c}
\text { j̀ba } \\
\text { 'king' }
\end{array} & \rightarrow & \begin{array}{l}
\text { xjôbâ } \\
\text { 'become king' }
\end{array}
\end{array}
$$

Examples below illustrate the conditions above.

Glide formation across morpheme boundaries
(b) $\mathrm{i}$
ètò ágbã̀
'hair' 'jaw'
ii.
òrú àmè
'season' 'water'

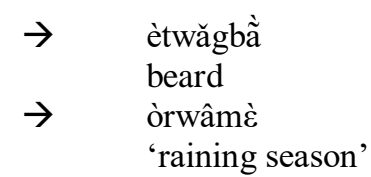

Glide formation within morpheme boundary
(c) $\mathrm{i}$.
/èkùć/
[غेkwĖ] 'nail' (finger or toe) 


$\begin{array}{lllll}\text { ii. } & \text { /ùgúàal } & \rightarrow & \text { [ùgwâ] } & \text { 'bone' } \\ \text { iii. } & \text { /ìguaa/ } & \rightarrow & \text { [ìgwâ] } & \text { 'knee' } \\ \text { iv. } & \text { /mí̀̇/ } & \rightarrow & {[\mathrm{mj} \varepsilon \text { ] }} & \text { 'lie down' }\end{array}$

The two syllable structure processes in Ikhin discussed so far, that is, vowel elision and glide formation have shown that either a vowel elides or undergoes a major class change, the tone which is grounded on it is not deleted, it relinks to the closest vowel to the right to form a contour tone (rising or falling) on the next vowel. Thus, tone exhibits stability in this language.

Stability is the survival of tone after either the deletion of segment on which it is grounded or the segment on which it is grounded has undergone a major class change by becoming a glide. Deletion of a tone bearing unit does not necessarily involve the deletion of tone. This confirms the earlier assertion that any process that involves the removal of a tone bearing unit must relate to stability and relate to the creation of contour tones. This paper's account of glide formation process and tone stability is formalised in the autosegmental representation below:

(i) غ̇kùćl $\rightarrow \quad$ [غ̇kwĒ] 'nail'

tonal tier

(ii)

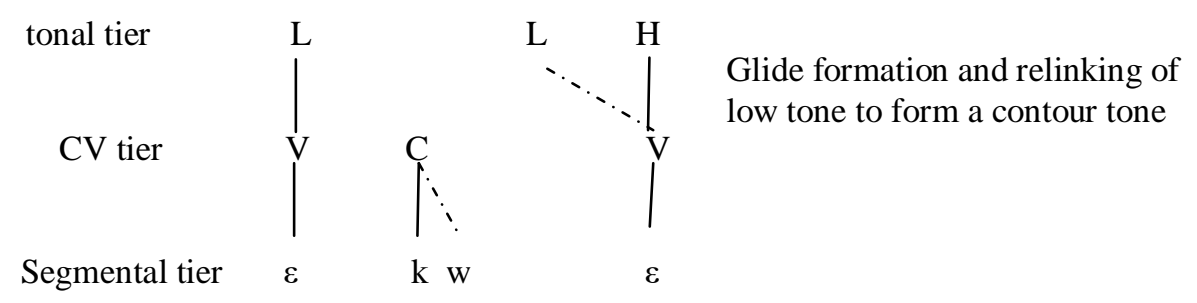

(iii)

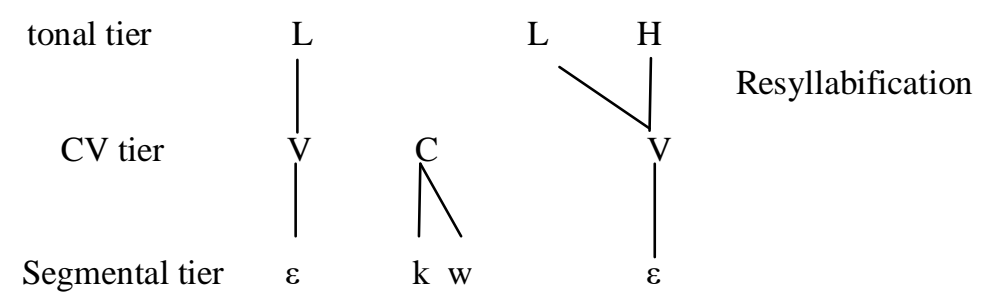

(iv)

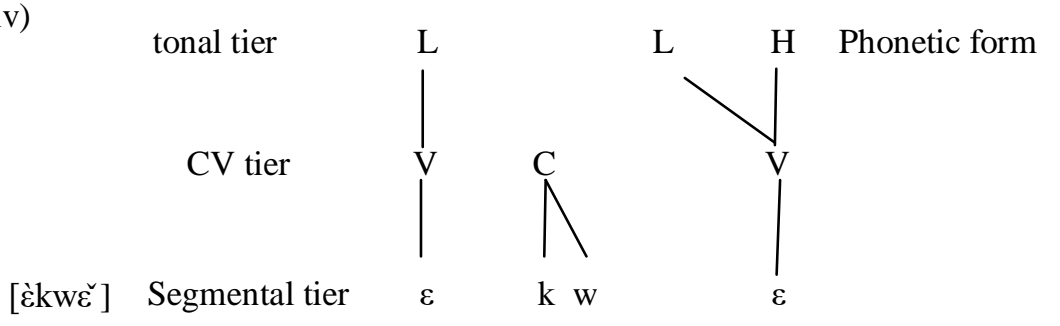

\section{NASALITY AND STABILITY}

The typical Edoid language is rich in nasals. In some of these languages, it is usually the case that these are seen as allophones of non-nasal phonemes Elugbe (1986). This implies that such nasals (apart from nasal consonants) are derived from their respective oral counterparts when they occur in the environment of nasalisation. Ikhin has twelve vowels made up of seven oral vowels and five phonemic nasal vowels.

\section{A. Consonant Nasalisation}

The phonemic nasal vowels in Ikhin are $/ \tilde{1} /, / \tilde{\varepsilon} /, / \tilde{a} /, / \tilde{u} / /$ and $/ \tilde{\mathrm{J}} /$. When consonants occur in their environment, they become nasalised. Specifically, these consonants are nasalised when they occur before the nasal vowels as in the following examples:

(i) /òrằ/ $\rightarrow$ [òrằ] 'tree' 


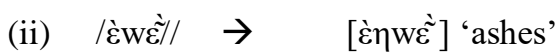

Within the framework we are adopting, nasality occurs on an autosegmental tier.

A lexical item is either marked positive for nasality or it is without underlying nasal specification. Nasality is linked to a segment only through association in a phonological representation, thus making it autonomous, that is, independent of the segment bearing it.

In autosegmental phonology, nasality either spreads on neighbouring segments or remains stable even in the absence of the segment to which it is linked when such segment elides or undergoes certain phonological processes.

In accounting for nasality in this way, Nasality Bearing Unit (NBU) has been proposed. Thus NBU in the underlying representation can be said to be the final vowel segment in the stem. This indicates that the autosegment is mapped onto only a $\mathrm{V}$ slot on the $\mathrm{CV}$ tier. The slot will then be on a nasal vowel in the underlying representation. In this proposal, all the nasalised segments within a stem are derived from the spreading of the nasal autosegment. Spreading here is from right to left.

Examples:

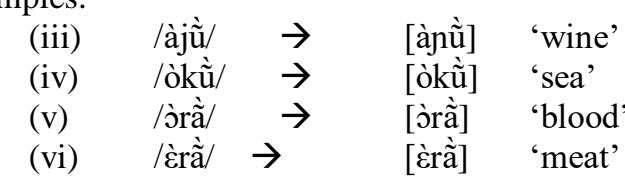

When consonants appear before substantial nasal vowels in Ikhin, they are nasalized or slightly nasalised. The preceding examples support the assertion that Ikhin's consonants are nasalized.A nasalized consonant is a consonant that, while being usually oral in a language, is articulated nasally due to an adjacent nasal sound, as it can be seen in www.archive.org.

\section{B. Vowel Nasalisation}

The seven oral and five nasal vowels in Ikhin are shown in the following tables

Fig: ..1

$\begin{array}{ll}\text { Oral vowels } & \\ \mathrm{i} & \mathrm{u} \\ \mathrm{e} & \mathrm{o} \\ \varepsilon & \mathrm{o}\end{array}$

a

Fig. 2

$\begin{array}{lll}\text { Nasal vowels } & \\ \tilde{1} & & \tilde{\mathrm{u}} \\ \tilde{\varepsilon} & & \tilde{\mathrm{o}}\end{array}$

In figure (2) above, there are no half close nasal phonemes /ẽ/ and /ô/. Each of the vowels in the two tables is a phoneme in Ikhin.

Ikhin displays a number of nasal sounds at the phonetic level. Each of the seven oral vowels in Ikhin may be phonetically nasalised if it occurs after nasal consonants $[\mathrm{m}]$ or $[\mathrm{n}]$. Spreading here is from left to right. The NBU is a consonant.

Examples:
(i) /òmòhél $\rightarrow$ [òmồhé] 'man'
(ii) /ùnù/ $\rightarrow$ [ùnuี̀] 'mouth'
(iii) /àmغ̀/ $\rightarrow \quad$ [àm气்] 'water'

The above show that oral vowels are nasalised after nasal consonants such as [n] and [m]. This paper's account of the stability of nasality is premised on the deletion of nasal vowel at morpheme boundary and its effect on nasality. At morpheme boundary, spreading mode is from left to right.

When a nasal vowel of monosyllabic verb elides, nasality relinks to the adjacent vowel across morpheme boundary. This is a demonstration of the stability of nasality in autosegmental framework.

Examples:

(a)

$$
\begin{aligned}
& \text { i. } \quad \text { jầ }, \quad \text { è̀ù̃ }, \rightarrow \text { nẽrũ } \\
& \text { 'cook' 'yam' cook yam } \\
& \begin{array}{ll}
\text { ii. } \quad \text { tõ̀ } & +\quad \text { òt } \\
\text { 'dig' } & \rightarrow \text { tồtè }
\end{array}
\end{aligned}
$$

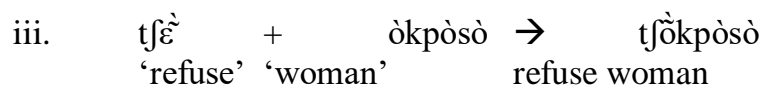

The stability of nasality is derived by the following autosegmental representation 


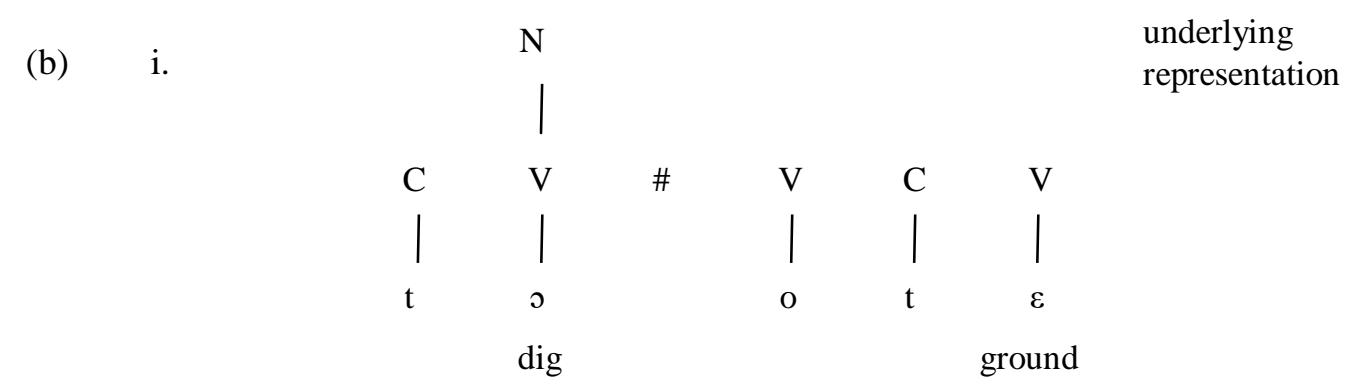

ii. $\mathrm{N}$

by vowel elision

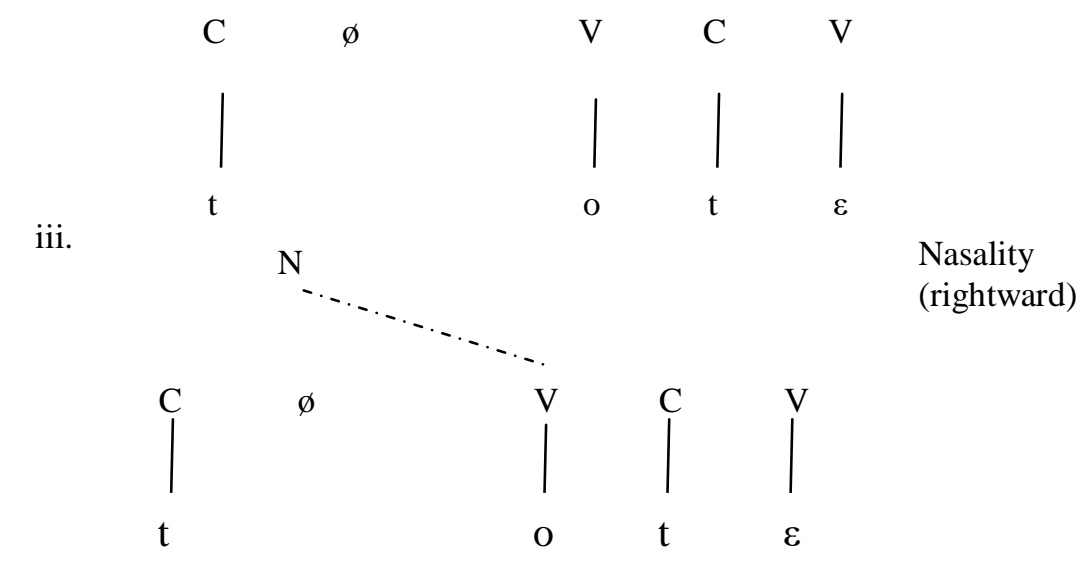

iv.<smiles>NNOP(I)I</smiles>

\section{CONCLUSION}

This research proved that Ikhin is a traditional African language with Edoid-like phonological features. According to Opoola and Olaide (2021), the syllable structure of the language discourages clusters of vowels within words or across word boundaries, vowel elision and glide formation are therefore two of the most common techniques for removing vowel sequence (cluster) in Ikhin. Further, the paper verified the independence of tone and nasality after the deletion of vowels to which these two phenomena are attached. The paper argued that the loss of a tone or nasality carrying unit does not always imply the loss of tone or nasality, and in fact, it seldom does. In this paper's description of contour tone formation, it was identified that any process involving the removal of a tone bearing unit must relate to stability and contour tone formation.

\section{REFERENCES}

[1] Amayo, A. (1976). "A Generative Phonology of Edo (Bini)” Unpublished Ph.D Thesis, Department of Linguistics and African Languages, University of Ibadan.

[2] Blench, R. (1989). New Benue - Congo.A Definition and Proposed Internal Classification. Arbeits Papiere. $17: 115$ - 147.

[3] Chomsky, N and Halle, M. (1968).The Sound Pattern of English. New York: Harper \& Row

[4] Egbokhare, F. (1990).“A Phonology of Emai”. Unpublished Ph.D Thesis, University of Ibadan.

[5] Elugbe, B. (1986). The Tone System of Ghotuo. Cambridge papers in Phonetics and Experimental Linguistics. 4: 1 - 21. 
[6] Elugbe, B. (1989). Edoid. In J.T. Bendor-Samuel (ed.). The Niger-Congo Languages, 291-304. New York: University Press of America.

[7] Elugbe, B. (1973). “A Comparative Edoid Phonology” Unpublished PhD Thesis, University of Ibadan

[8] Folarin, Y. (1982) Aspects of the Phonetics and Phonology of Ikhin. An unpublished M.A. Dissertation, University of Ibadan.

[9] Goldsmith, J. (1976). "Autosegmental Phonology”. Unpublished PhD. Thesis. Massachusetts Institute of Technology (MIT)

[10] Goldsmith, J. (1990). Autosegmental and Metrical Phonology. Oxford: Basil Blackwell.

[11] Kenstowicz, M. \& Park, C. (2006). Laryngeal features and tone in Kyungsang Korean: A Phonetic Study. Studies in Phonetic, Phonology and Morphology, 20(10), p100. Retrieved June 8, 2021.

[12] Kiparsky, P. (1968). "How abstract is Phonology?” Bloomington. Indiana: Indiana University Linguistics Club

[13] Leben, W. (1973). The Role of tone in Segmental Phonology. In L. Hyman (ed.) Consonant Types and Tones southern California: Occasional papers in Linguistic No. 1: 117 - 149.

[14] Oladimeji, O. (2010). A Phonology of Ikhin, an Edoid Language in South-South, Nigeria. Unpublished Ph.D Thesis, University of Ibadan.

[15] Oladimeji, O. (2013). The Tone System of Ikhin. Open Science Repository Language and Linguistics. www.open-sciencerepository.com

[16] Opoola Bolanle T., and Olaide Oladimeji. (2021). 'Vowel Elision in Ikhin', an Edoid Language in South-South, Nigeria. Journal of Language Teaching and Research, Vol.12, No 3. UK Academy. http://dx.doi.org/10.17507/jltr.1203.04.

[17] Ostendorp, M. (2005). Autosegmental Phonology. An Overview of some of the basic principles of Autosegmental Phonology. http:/en.wikipedia org./wiki:21:4:05.

[18] Pike, K. (1948). Tone Languages. Ann arbour: University of Michigan Press.

[19] Welmers, W. (1973). African Language Structures. Los Angeles: University of California Press.

[20] journal.ikipsiliwangi.ac.id

[21] www.archive.org.

[22] www.ling.mq.edu.au

[23] www.open-science-repository.com

[24] www.studylove.org

[25] www.vanoostendorp.nl

[26] www.web.mit.edu

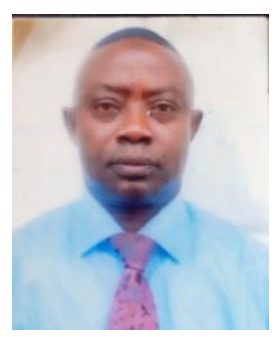

Olaide Abduwaheed Oladimeji was born in Ibadan, Nigeria 1969. He received his $\mathrm{PhD}$ degree in Linguistics from University of Ibadan in 2010.

He is a lecturer 1 in the Department of Linguistics and Languages, Federal University, Oye-Ekiti, Nigeria. His research interests include Phonology and Syntax of African languages.

Dr. Oladimeji is member of Linguistics Association of Nigeria.

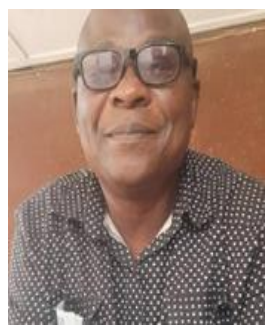

Tajudeen Bolanle Opoola was born in Oyo, Nigeria in 1959. He received his PhD degree in Linguistics from University of Calabar, Nigeria in 2001. He is currently a Professor in the Department of Linguistics and Languages, Federal University, Oye-Ekiti, Nigeria. His research interests include Applied Linguistics and African languages.

Professor Opoola is a member of Linguistics Association of Nigeria and Patron, Association of Nigerian Authors, Oyo State branch, Nigeria. 